\title{
Antimycobacterial potential of the juniper berry essential oil in tap water
}

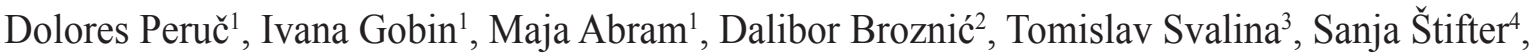 \\ Mladenka Malenica Staver ${ }^{5}$, and Brigita Tićac ${ }^{1}$
}

\begin{abstract}
Department of Microbiology and Parasitology ${ }^{1}$, Department of Chemistry and Biochemistry², Faculty of Medicine, University of Rijeka, Department of Agricultural Karst, Polytechnic Marko Marulic, Knin ${ }^{3}$, Department of Pathology, Faculty of Medicine ${ }^{4}$, Department of Biotechnology, University of Rijeka, Rijeka, Croatia
\end{abstract}

[Received in January 2017; Similarity Check in January 2017; Accepted in March 2018]

Mycobacterium avium complex-related diseases are often associated with poorly maintained hot water systems. This calls for the development of new control strategies. The aim of this study was to investigate the activity of essential oils (EOs) from the Mediterranean plants, common juniper, immortelle, sage, lavandin, laurel, and white cedar against Mycobacterium avium ssp. avium, Mycobacterium intracellulare, and Mycobacterium gordonae in culturing broth and freshwater as their most common habitat. To do that, we developed a new method of water microdilution to determine their minimal effective concentrations (MEC). The most active EO was the one from the common juniper with the MEC of $1.6 \mathrm{mg} \mathrm{mL}^{-1}$. Gas chromatography / mass spectrometry the juniper EO identified monoterpenes (70.54 \%) and sesquiterpenes $(25.9 \%)$ as dominant component groups. The main monoterpene hydrocarbons were $\alpha$-pinene, sabinene, and $\beta$-pinene. The juniper EO significantly reduced the cell viability of $M$. intracellulare and $M$. gordonae at MEC, and of M. avium at 2xMEC. Microscopic analysis confirmed its inhibitory effect by revealing significant morphological changes in the cell membrane and cytoplasm of all three bacteria. The mode of action of the juniper EO on the cell membrane was confirmed by a marked leakage of intracellular material. Juniper EO has a great practical potential as a complementary or alternative water disinfectant in hot water systems such as baths, swimming pools, spa pools, hot tubs, or even foot baths/whirlpools.

KEY WORDS: Helichrysum italicum; Juniperus communis; Lavandula hybrida; Laurus nobilis; minimum effective concentration; Mycobacterium avium; Mycobacterium gordonae; Mycobacterium intracellulare; nontuberculous mycobacteria; Salvia officinalis; tap water; Thuja occidentalis; water infections; water microdilution

Nontuberculous mycobacteria (NTM) are a heterogeneous group of environmental bacteria, most commonly isolated from water, soil, dust, and animals. Some species may be pathogenic to humans, especially the immunocompromised ones, and can cause pulmonary and skin infections (1). Humans are most often exposed to NTM through freshwater (2-5). In the aquatic environment, NTM form biofilms to resist standard decontamination and disinfection $(2,3,6,7)$. The growing number of resistant microorganisms calls for new methods, and plants offer promising antimicrobial activity (8), their essential oils (EOs) in particular.

EOs are volatile, natural, complex compounds, produced by aromatic plants as secondary metabolites. Hence their strong aroma (9). They mainly consist of terpenoids and terpenes (especially hemiterpenes, monoterpenes, sesquiterpenes, and diterpenes), and a variety of aromatic and aliphatic compounds (acids, alcohols, aldehydes, acyclic esters, or lactons) (9-11). Their antimicrobial activity depends on their chemical

Correspondence to: Dolores Peruč, Department of Microbiology and Parasitology, Faculty of Medicine, University of Rijeka, Braće Branchetta 20,51000 Rijeka, e-mail:dolores.peruc@uniri.hr composition, functional groups, and synergism between components, if there is one $(9,10,12)$. Even EOs of the same plant differ in composition due to a number of factors such as geographical location, plant maturity and age, part of the plant used, and distillation method. A number of studies have already investigated the antimicrobial effects of EOs against NTM in a variety of matrices, but none that we know of used tap water as the matrix, even though it is their most common natural environment and source of infection as well, in which they develop higher resistance than in artificial (laboratory) environments $(9,13)$. Our aim was, therefore, to investigate the antimycobacterial effectiveness of EOs from Mediterranean plants in tap water. To do that, we developed a new method of water microdilution to determine their minimal effective concentrations (MEC).

\section{MATERIALS AND METHODS}

\section{Essential oils, gas chromatography, and compounds}

For the experiments we used natural commercial EOs distilled from the wild common juniper (Juniperus 
communis), immortelle (Helichrysum italicum), sage (Salvia officinalis), lavandin (Lavandula hybrida), laurel (Laurus nobilis), and white cedar (Thuja occidentalis) growing on the Croatian coast. The oils were purchased from IREKS AROMA, Zagreb, Croatia. The most common organic compound of the terpene class in the EOs, $\alpha$-pinene, was purchased from Sigma-Aldrich (St. Louis, MO, USA).

Having determined the most efficient oil, we then analysed it for components with an Agilent gas chromatograph/mass spectrometer (GC-MS) model 7820A equipped with a mass selective detector (MSD) model $5977 \mathrm{E}$ and a HP-5MS column (5\% phenylmethylpolysiloxane) (Agilent Technologies, Palo Alto, CA, USA). The GC conditions were similar to those described previously (14). In brief, the oven temperature started at $70{ }^{\circ} \mathrm{C}$ for $2 \mathrm{~min}$, then ramped from 70 to $200^{\circ} \mathrm{C}$ at $3{ }^{\circ} \mathrm{C} \mathrm{min}^{-1}$, and remained isothermal at $200{ }^{\circ} \mathrm{C}$ for $15 \mathrm{~min}$. The carrier gas was helium (flow rate: $1.0 \mathrm{~mL} \mathrm{~min}{ }^{-1}$ ). The MSD (EI mode) was operated at $70 \mathrm{eV}$, and the range was 30-300 atomic mass units (amu), as reported earlier $(14,15)$. Individual compound peaks were identified by comparing their retention indices (relative to $\mathrm{C}_{9}-\mathrm{C}_{25} n$-alkanes) with those of the available authentic samples and literature data (16) and by comparing their mass spectra with the Wiley 09 MS library (Wiley, New York, NY, USA) and NIST14 (D-Gaithersburg) database. The percentage of the composition was calculated from the GC peak using the normalisation method (without correction factors).

\section{Tap water sampling}

For the experiments with tap water we used water from the public water supply of the city of Rijeka with the following properties: salinity $0, \mathrm{pH} 7.5-8.0$, and conductivity $216-300 \mu \mathrm{S} \mathrm{cm}^{-1}$. In other words, it was medium hard water. We poured the water in a glass bottle and left it at room temperature to dechlorinate for two days. Then we sterilised it by autoclaving at $121{ }^{\circ} \mathrm{C}$ for $15 \mathrm{~min}$, cooled to room temperature, and stored at $4{ }^{\circ} \mathrm{C}$ until use.

\section{Bacterial cultures}

For the experiments we used the following bacterial strains: Mycobacterium avium ssp. avium (serotype 2) ATCC 25291 (M. avium), Mycobacterium intracellulare ATCC 13950 (M. intracellulare), and Mycobacterium gordonae ATCC 14470 (M. gordonae). The strains were cultivated twice in Middlebrook $7 \mathrm{H} 9$ broth $(7 \mathrm{H} 9$, Difco, Detroit, Michigan, USA) with $10 \%$ albumin-dextrosecatalase (ADC, Biolife Italiana, Milano, Italy) and $0.05 \%$ Tween 80 (Tw80, Biolife Italiana, Milano, Italy) at $30{ }^{\circ} \mathrm{C}$ (M. gordonae) or $37^{\circ} \mathrm{C}$ (M. avium and M. intracellulare) for two weeks to obtain $10^{8} \mathrm{CFU} \mathrm{mL} \mathrm{m}^{-1}$. The bacteria were then frozen at $-80{ }^{\circ} \mathrm{C}$ with $10 \%$ glycerol. For each experiment, an aliquot was thawed and cultured in $7 \mathrm{H} 9$ for two weeks and then the culture was incubated on Middlebrook $7 \mathrm{H} 10$ agar (7H10, Difco) with $10 \%$ oleic acid-albumin-dextrose-catalase (OADC, Biolife Italiana) and $0.05 \%$ Tw80 at $30{ }^{\circ} \mathrm{C}(M$. gordonae $)$ or $37{ }^{\circ} \mathrm{C}(M$. avium and $M$. intracellulare) for two more weeks. The initial inocula were later verified by diluting and plating the culture onto $7 \mathrm{H} 10$ with $10 \% \mathrm{OADC}$ and $0.05 \%$ Tw80 and by incubating them at $30{ }^{\circ} \mathrm{C}($ M. gordonae $)$ or $37^{\circ} \mathrm{C}($ M. avium and $M$. intracellulare) for four to six weeks before the colonies were counted (17).

\section{Determination of minimum inhibitory concentration and minimum bactericidal concentration in broth}

Minimum inhibitory concentrations (MIC) and minimum bactericidal concentrations (MBC) of the tested EO samples were determined using a broth microdilution method, as follows: EO was double diluted in $7 \mathrm{H} 9$ with $10 \%$ OADC and $0.05 \%$ Tw80, starting from 0.1 to the final $51.2 \mathrm{mg} \mathrm{mL}^{-1}$ in a sterile 96-well microtitre plate (Vacutest Kima s.r.1., Arzergrande, Italy). The final concentration of the solvent dimethyl sulphoxide (DMSO) was about $10 \%$. Each dilution was mixed with a mycobacterial suspension ( $1 \times 10^{6} \mathrm{CFU} \mathrm{mL}^{-1}$ per well) and resazurin $(0.015 \%$ solution $)$ (Sigma-Aldrich) to reach the final volume of $200 \mu \mathrm{L}$. Resazurin is an oxidation-reduction indicator used for the evaluation of cell growth. It is a blue non-fluorescent and non-toxic dye that becomes pink and fluorescent when reduced to resorufin by oxidoreductases in viable cells (18). In addition to negative sterile control (without bacteria), we also used a mixture with amikacin for positive control. The plates were incubated at $30^{\circ} \mathrm{C}(M$. gordonae) or $37^{\circ} \mathrm{C}$ (M. avium and M. intracellulare) and swirled at $120 \mathrm{rpm}$ with a Heidolph UNIMAX 1010 shaker (Schwabach, Germany) for $24 \mathrm{~h}$. MIC was the lowest concentration without change in colour. MBC was determined by inoculating the dilutions that showed no colour change with $M$. gordonae or $M$. avium or $M$. intracellulare on $7 \mathrm{H} 10$ supplemented with $10 \%$ OADC and by incubating them at $30^{\circ} \mathrm{C}($ M. gordonae $)$ or $37^{\circ} \mathrm{C}$ ( $M$. avium and $M$. intracellulare) for another four weeks. MBC was the lowest concentration of EO that killed $\geq 99 \%$ of the bacteria. The concentrations are expressed in $\mathrm{mg} \mathrm{mL}^{-1}$ (18).

\section{Determination of minimal effective concentration in tap water}

To determine the minimal effective concentration (MEC) in sterile tap water, we repeated the same procedure as above, but instead of $7 \mathrm{H} 9$ with $10 \%$ OADC and $0.05 \%$ Tw80 broth we only used sterile tap water mixed with $0.05 \%$ Tw80. MEC was the lowest concentration of EO that killed $\geq 99 \%$ of the bacteria. The concentration is expressed in $\mathrm{mg} \mathrm{mL}^{-1}$.

\section{Determining mycobacterial survival in sterile tap water}

This method allows the characterisation of the antibacterial activity of an EO over time. We prepared a 
suspension of $10^{8} \mathrm{CFU} \mathrm{mL} \mathrm{mL}^{-1}$ of each mycobacterial strain in sterile tap water with $0.05 \%$ Tw80 and then added half or the entire MEC of the EO and incubated the mix by stirring it at $30^{\circ} \mathrm{C}$ (M. gordonae) or $37^{\circ} \mathrm{C}$ (M. avium and M. intracellulare). On days 0,1 , and 2 , we removed $100 \mu \mathrm{L}$ of the suspension and determined bacterial CFU $\mathrm{mL}^{-1}$. For growth control, we used unexposed bacteria (19).

\section{Determining bacteriolysis}

This method determines if there is a bacteriolytic action by measuring the absorbance at $620 \mathrm{~nm}$, as non-lysed bacteria absorb at $620 \mathrm{~nm}$. If there is a bacteriolysis, the absorbance at $620 \mathrm{~nm}$ will decrease over time. Bacterial suspension $\left(10^{8} \mathrm{CFU} \mathrm{mL} \mathrm{m}^{-1}\right)$ was placed in a sterile tube in the absence (negative control) or in the presence of EO at two concentrations: one MEC and the other two times the MEC. The obtained suspensions were then incubated with agitation for $24 \mathrm{~h}$, after which we measured the absorbance at $620 \mathrm{~nm}$. For the blank we used sterile tap water with $0.05 \%$ Tw 80 and EO at MEC or 2xMEC. The results are expressed as the relative optical density $\left(\mathrm{OD}_{620}\right)(20)$.

\section{Leakage of cellular metabolites}

Two-week bacterial cultures in $7 \mathrm{H} 9$ with $10 \% \mathrm{ADC}$ and $0.05 \%$ Tw80 were transferred into sterile centrifuge tubes and centrifuged at $3500 \mathrm{~g}$ for $10 \mathrm{~min}$. The supernatant was discarded and the pellet resuspended in sterile tap water. The suspension was centrifuged and resuspended twice in sterile tap water with $0.05 \%$ Tw80. OD 600 of each sample was adjusted to around 1.0, which corresponds to $10^{8} \mathrm{CFU} \mathrm{mL} \mathrm{m}^{-1}$, and the bacterial counts verified by diluting and plating ten-fold serial dilutions. Aliquots of each bacterial suspension were then placed in sterile flasks and mixed with the EO at MEC or 2xMEC. Flasks containing only bacterial cultures served as controls. After a 24-hour incubation at $30^{\circ} \mathrm{C}($ M. gordonae $)$ or $37^{\circ} \mathrm{C}($ M. avium and $M$. intracellulare), the suspensions were centrifuged at $3500 \mathrm{~g}$ for $10 \mathrm{~min}$. The supernatants were used to quantitate DNA at absorbance of $260 \mathrm{~nm}$ (A260) and proteins at $280 \mathrm{~nm}(\mathrm{~A} 280)(21,22)$.

\section{Determining the EO DPPH radical scavenging activity (RSA)}

The radical scavenging activity (RSA) of the EO was determined by measuring 2,2-diphenyl-1-picrylhydrazyl (DPPH·) inhibition (23). We added the EO in MEC to a freshly prepared, $0.1 \mathrm{mmol} \mathrm{L}^{-1} \mathrm{DPPH}$ solution in ethyl acetate in order to obtain a $4 \% \mathrm{w} / \mathrm{v}$ EO solution. After $10 \mathrm{~s}$ of vigorously mixing on a vortex agitator, the absorbance of the mixture was measured spectrophotometrically (Cary 100 Bio WINUV, Mulgrave, Australia) at $515 \mathrm{~nm}$ every minute over 60 min until the reaction reached a steady state. The total RSA of the EO was expressed as the percentage of DPPH left after $60 \mathrm{~min}$, as follows:
DPPH' scavenging $(\%)=\frac{A_{0}-A_{\text {sample }}}{A_{0}} \cdot 100$

where $\mathrm{A}_{0}$ is the absorbance of the ethyl acetate DPPH solution without the sample as negative control and $\mathrm{A}_{\mathrm{s}}$ the absorbance of the mix at $\mathrm{t}=60 \mathrm{~min}$.

DPPH inhibition was compared with the standard curve of Trolox (6-hydroxy-2,5,7,8-tetramethylchroman-2carboxylic acid, Trolox, Sigma-Aldrich Chemie, Germany) in the range of $0-0.21 \mathrm{mmol} \mathrm{L}^{-1}$. In quantitative terms, radical scavenging was expressed as mmoles of Trolox equivalents per $\mathrm{kg}$ of $\mathrm{EO}$ (mmol TEAC $\left.\mathrm{kg}^{-1} \mathrm{EO}\right)$.

\section{Transmission electron microscopy}

To evaluate structural changes, we analysed the morphologies of the bacteria exposed to the selected EO. Briefly, M. avium was grown on $7 \mathrm{H} 10$ with $10 \%$ OADC and $0.05 \%$ Tw80 for four to six weeks. Ten microliters of

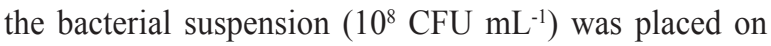
Formwar-coated copper grids (Agar Scientific Ltd, Essex, United Kingdom) for $2 \mathrm{~min}$. After that, the excess of liquid was wicked off the grids with Watman no. 3 filter paper. The bacteria remaining on the grids were stained with $1 \%$ phosphotungstic acid (PTA; Sigma-Aldrich) for $1 \mathrm{~min}$, and the excess of PTA carefully removed with filter paper. The grids were then left to dry on air for a few minutes. The bacteria were inspected on a transmission electron microscope (JEM-2100F, Jeol, Japan).

\section{Statistical analysis}

The results were analysed with the STATISTICA 12. 0 (StatSoft, Tulsa, OK, USA) and expressed as means \pm standard deviation (SD). The Kolmogorov-Smirnov test confirmed normal distribution. Differences between the groups of samples were analysed with the Kruskal-Wallis test by ranks, while the effects of EO on the mycobacteria were tested with the Mann-Whitney U test. Differences with $p<0.05$ were considered statistically significant.

\section{RESULTS}

The most effective EO tested against the selected mycobacteria in this study was that of the common juniper, with the MIC/MBC in broth and MEC in sterile tap water of $1.6 \mathrm{mg} \mathrm{mL}^{-1}$. Table 1 shows the efficiency of all tested EOs in both media.

Spectrometry of the juniper EO identified 36 components, which made $96.44 \%$ of the oil. The main components were monoterpenes $(70.54 \%)$ and sesquiterpenes (25.9\%) (Table 2).

Figure 1 shows the inhibition of the mycobacteria with the juniper EO at half the MEC and full MEC.

Figure 2 shows the bacteriolytic action of the juniper $\mathrm{EO}$ at MEC and double the MEC over $24 \mathrm{~h}$, while Figures 3 and 4 show the protein $(280 \mathrm{~nm})$ and DNA $(260 \mathrm{~nm})$ 
Table 1 Minimum inhibitory concentration (MIC), minimum bactericidal concentration (MBC), and minimum effective concentration (MEC) against three mycobacterial strains

\begin{tabular}{|c|c|c|c|c|c|c|}
\hline \multirow{2}{*}{ Essential oil } & \multicolumn{3}{|c|}{$\begin{array}{c}\text { MIC / MBC in } 7 \mathrm{H} 9 \text { broth } \\
\left(\mathrm{mg} \mathrm{mL}^{-1}\right)\end{array}$} & \multicolumn{3}{|c|}{$\begin{array}{c}\text { MEC in sterilised tap water } \\
\left(\mathrm{mg} \mathrm{mL}^{-1}\right)\end{array}$} \\
\hline & M. avium & M. intracellulare & M. gordonae & M. avium & M. intracellulare & M. gordonae \\
\hline Thuja occidentalis & 6.4 / 6.4 & $6.4 / 6.4$ & $12.8 / 12.8$ & $>51.2$ & $>51.2$ & $>51.2$ \\
\hline Juniperus communis & $1.6 / 1.6$ & $1.6 / 1.6$ & $1.6 / 1.6$ & 1.6 & 1.6 & 1.6 \\
\hline Helichrysum italicum & $3.2 / 3.2$ & $3.2 / 3.2$ & $3.2 / 3.2$ & 3.2 & 3.2 & 1.6 \\
\hline Laurus nobilis & $12.8 / 6.4$ & $12.8 / 6.4$ & $3.2 / 1.6$ & 25.6 & 25.6 & 25.6 \\
\hline Lavandula hybrida & $3.2 / 1.6$ & $3.2 / 1.6$ & $6.4 / 3.2$ & 12.8 & 12.8 & 25.6 \\
\hline Salvia officinalis & $12.8 / 12.8$ & $25.6 / 12.8$ & $6.4 / 1.6$ & 12.8 & 25.6 & 25.6 \\
\hline$\alpha$-pinene & $12.8 / 12.8$ & $12.8 / 12.8$ & $6.4 / 1.6$ & 12.8 & 12.8 & 12.8 \\
\hline Amikacin & $0.004 / 0.008$ & $0.004 / 0.008$ & $0.008 / 0.008$ & ND & ND & ND \\
\hline
\end{tabular}

ND - not determined
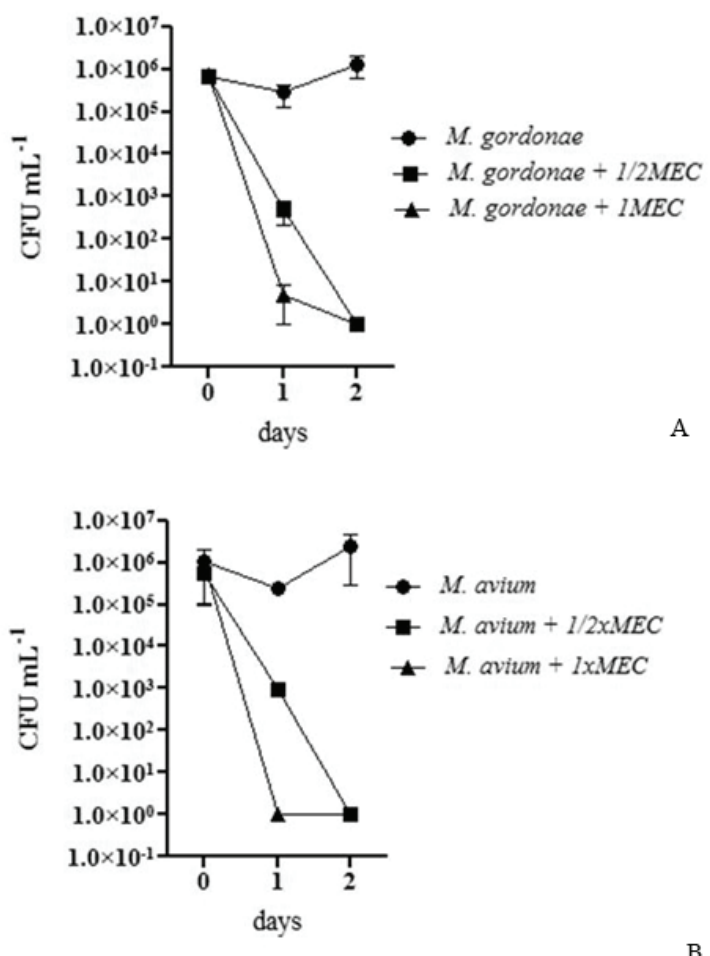

B

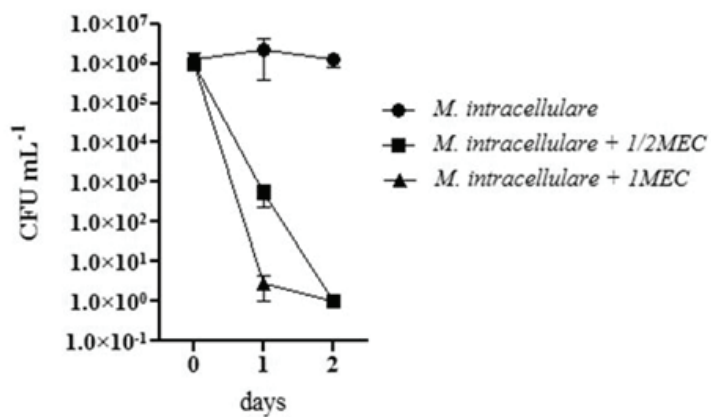

$\mathrm{C}$

Figure 1 Time-kill curves of $\mathrm{M}$. avium $(A)$, M. intracellulare (B), and $\mathrm{M}$. gordonae $(C)$ in sterile tap water in control suspensions $(\bullet)$ and after treatment with juniper EO at half the MEC (ロ) and $\operatorname{MEC}(\mathbf{\Delta})$ leakage due to cell membrane damage at the same EO concentrations. Only $M$. avium did not show a significant leakage at MEC. Morphological changes were clear in the cells of all three bacteria exposed to the juniper EO; cell cytoplasm was destroyed and the cells were clustered, forming small buds on the cell wall (Figure 5B).

As for the DPPH radical-scavenging activity, the juniper EO MEC resulted in a $21.9 \%$ and $26.3 \%$ DPPH inhibition after 30 and $60 \mathrm{~min}$, respectively. The 60 -minute inhibition corresponded to $0.0811 \mathrm{mmol} \mathrm{kg}^{-1} \mathrm{TEAC}$.

\section{DISCUSSION}

Some authors have shown that the common juniper EO content varies with the geographical origin of the plant, maturity of the berries, age of the plant, meteorological and other microclimatic conditions (e. g. temperature), as well as harvesting and distillation methods $(24,25)$. Our juniper EO was dominated by $\alpha$-pinene, which is in agreement with reports from Croatia (16.9-29.17\%) $(26,27)$, Italy $(6.41-$ $52.91 \%$ ) (28), Greece (41.3\%) (29), Bulgaria (51.4\%) (30), Macedonia (15.59-43.19\%) (24), Kosovo (23$36.2 \%)(31,32)$, Serbia (36.6-40.5\%) (33), and Estonia $(54.6 \%)$ (34). Monoterpene hydrocarbons, to which $\alpha$-pinene belongs, can easily pass through the cell membrane lipid bilayer, most probably by diffusion (35). Sikkema et al. (36) reported that cyclic hydrocarbons swell the cell membrane bilayer and increase its permeability in Escherichia coli. This permeability is associated with the loss of ions and therefore a drop in membrane potential, collapse of the proton pump, and depletion of the ATP pool. Once the EO has entered the cell, it can coagulate the cytoplasm and damage lipids and proteins. As the cell wall and membrane are already damaged, the cell breaks and macromolecules leak out $(8,35-38)$. Bakkali et al. (9) also reported much greater sensitivity of the dividing cells, probably because EO penetrated more efficiently at the budding sites. Our morphological analysis has confirmed 
Table 2 Chemical composition of the juniper EO determined with gas chromatography / mass spectrometry

\begin{tabular}{|c|c|c|c|}
\hline No. & Compound name and class & RI & Area $(\%)$ \\
\hline \multicolumn{3}{|c|}{ Monoterpene hydrocarbons } & 66.29 \\
\hline 1. & $\alpha$-Thujene & 933 & 1.94 \\
\hline 2. & $\alpha$-Pinene & 944 & 31.13 \\
\hline 3. & Camphene & 957 & 0.51 \\
\hline 4. & Verbene & 962 & 0.14 \\
\hline 5. & Sabinene & 980 & 9.95 \\
\hline 6. & $\beta$-Pinene & 983 & 8.50 \\
\hline 7. & $\beta$-Myrcene & 994 & 4.80 \\
\hline 8. & $\alpha$-Terpinene & 1021 & 0.44 \\
\hline 9. & $p$-Cymene & 1030 & 2.45 \\
\hline 10. & Limonene & 1034 & 4.53 \\
\hline 11. & $\gamma$-Terpinene & 1064 & 0.88 \\
\hline 12. & $\alpha$-Teroinolene & 1091 & 1.02 \\
\hline \multicolumn{3}{|c|}{ Monoterpene alcohols } & 3.81 \\
\hline 13. & Linalool & 1101 & 0.31 \\
\hline 14. & trans-Pinocarveol* $^{*}$ & 1141 & 0.22 \\
\hline 15. & 4-Terpineol & 1182 & 2.76 \\
\hline 16. & p-cymen-8-ol & 1189 & 0.19 \\
\hline 17. & $\alpha$-Terpineol & 1193 & 0.33 \\
\hline \multicolumn{3}{|c|}{ Monoterpene esters } & 0.44 \\
\hline 18. & $\alpha$-Fenchyl acetate & 1288 & 0.44 \\
\hline \multicolumn{3}{|c|}{ Sesquiterpene hydrocarbons } & 24.86 \\
\hline 19. & $\alpha$-Cubebene & 1353 & 1.34 \\
\hline 20. & $\beta$-Elemene & 1393 & 2.34 \\
\hline 21. & Isoledene & 1402 & 0.25 \\
\hline 22. & trans- $\beta$-Caryophyllene & 1421 & 2.95 \\
\hline 23. & $\gamma$-Elemene & 1436 & 0.52 \\
\hline 24. & $\alpha$-Humulene & 1456 & 2.44 \\
\hline 25. & trans- $\beta$-Fernesene & 1460 & 0.44 \\
\hline 26. & $\alpha$-Amorphene & 1479 & 1.09 \\
\hline 27. & Germacrene-D & 1483 & 4.21 \\
\hline 28. & $\beta$-Selinene & 1487 & 0.75 \\
\hline 29. & $\alpha$-Selinene & 1495 & 1.09 \\
\hline 30. & $\alpha$-Muurolene & 1501 & 0.77 \\
\hline 31. & $\delta$-Cadinene & 1526 & 3.33 \\
\hline 32. & $\alpha$-Cadinene & 1540 & 0.18 \\
\hline 33. & Garmacrene-B & 1558 & 2.83 \\
\hline 34. & T-Muurolol & 1644 & 0.33 \\
\hline \multicolumn{3}{|c|}{ Sesquiterpeneoxydes } & 1.04 \\
\hline 35. & Spathulenol & 1579 & 0.61 \\
\hline 36. & Caryophyllene oxide & 1584 & 0.43 \\
\hline \multicolumn{3}{|c|}{ Total identified components (\%) } & 96.44 \\
\hline
\end{tabular}

$R I$ - retention index relative to the $C_{9}-C_{25} n$-alkanes; *the closest isomer; exact isomer not identified 


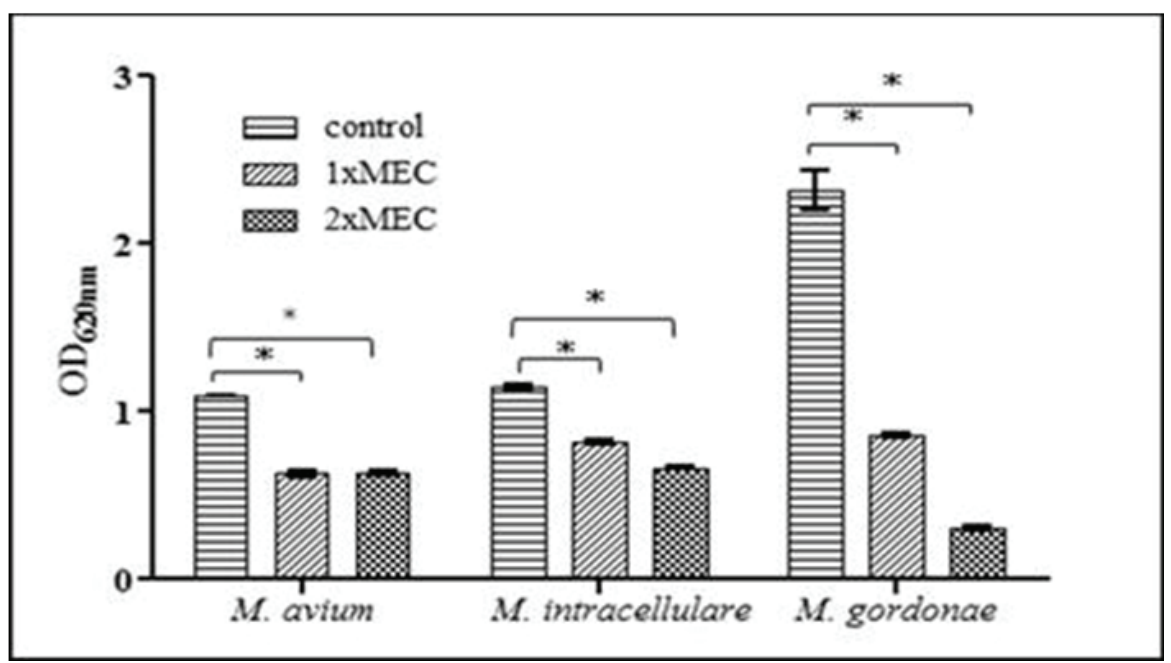

Figure 2 Bacteriolytic effects of the juniper EO in sterile tap water after $24 \mathrm{~h}$ measured with absorbance at $620 \mathrm{~nm}$ Control - unexposed to juniper EO; EO - essential oil; MEC - minimum effective concentration

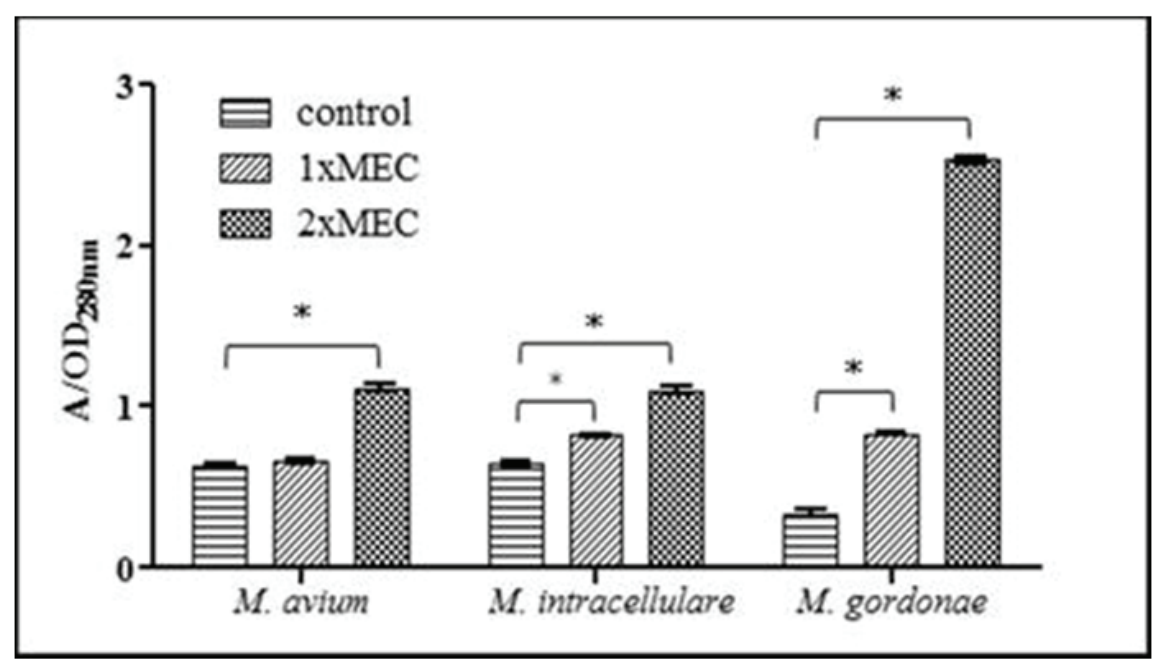

Figure 3 Protein leakage after $24 \mathrm{~h}$ of treatment with the juniper EO measured with absorbance at $280 \mathrm{~nm}$ Control - unexposed to juniper EO; EO - essential oil; MEC - minimum effective concentration

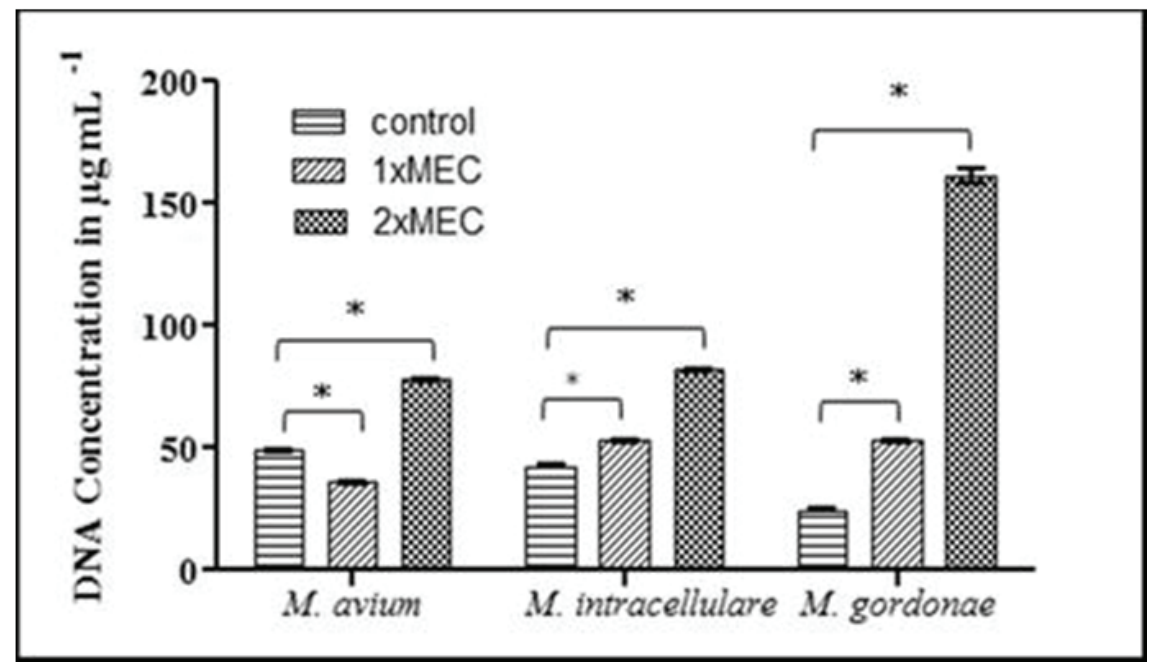

Figure 4 DNA leakage after $24 \mathrm{~h}$ of treatment with the juniper $E O$, measured with absorbance at $260 \mathrm{~nm}$ Control - unexposed to juniper EO; EO - essential oil; MEC - minimum effective concentration 


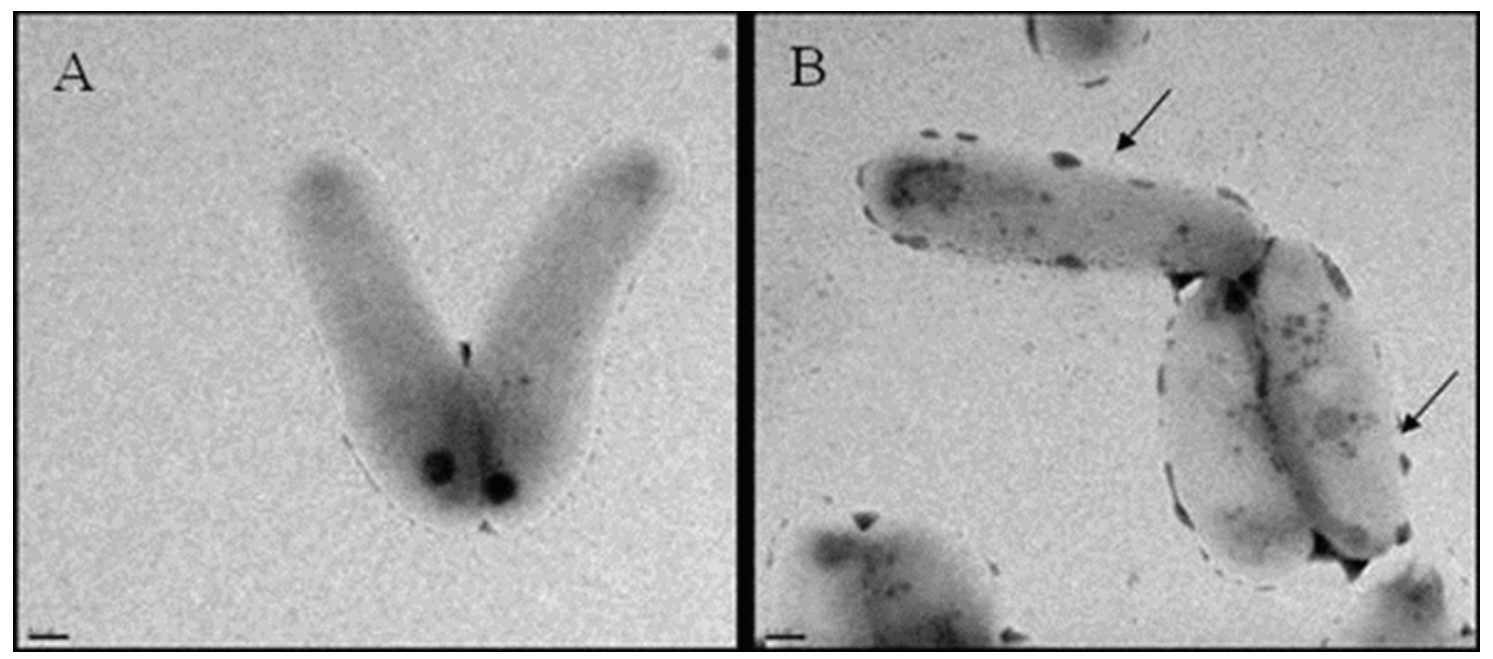

Figure 5 Morphological comparison of (A) control M. avium cell and (B) M. avium cell treated with the juniper EO at double the MEC for $24 \mathrm{~h}$

Control - unexposed to juniper EO; EO - essential oil; MEC - minimum effective concentration

that EOs penetrate the wall and wreak havoc in the cell. Pinenes have very low water solubility but relatively high antimicrobial activities $(37,39)$. Such effects of the monoterpenes menthol, thymol, and linalyl acetate have already been described against Staphylococcus aureus and E. coli (37). Interestingly, even though our juniper EO was dominated by $\alpha$-pinene, it exhibited three-times stronger inhibition than $\alpha$-pinene alone (Table 1). This may point to a synergism with other main components in the oil.

Our results have also pointed out differences in MBCs and MECs of the white cedar, laurel, lavandin, and sage EOs when we changed the culture medium from broth to water (Table 1). The reason, we believe, is that, being a medium rich in nutrients, $7 \mathrm{H} 9$ promotes NTM division, which renders them much more sensitive to the effects of EOs, whereas nutrient-poor water forces the mycobacteria to adapt and renders them more resistant. However, the change of the medium did not affect the efficiency of the juniper EO, which singles it out as a promising natural and safe way to control mycobacteria in fresh water as source of human infection (7). It could be used as a complementary or alternative disinfectant of hot water systems like baths, swimming pools, spa pools, hot tubs, or even foot baths/ whirlpools.

\section{Acknowledgments}

This work was funded by the University of Rijeka, Croatia (grants No. 13.06.2.2.60 and 13.06.1.1.07). The funders had no role in study design, data collection and analysis, or preparation of the manuscript.

\section{REFERENCES}

1. LeDantec C, Duguet JP, Montiel A, Dumoutier N, Dubrou $\mathrm{S}$, Vincent $\mathrm{V}$. Occurrence of mycobacteria in water treatment lines and in water distribution systems. Appl Environ Microbiol 2002;68:5318-25. PMCID: PMC129932

2. Sousa S, Bandeira M, Carvalho PA, Duarte A, Jordao L. Nontuberculous mycobacteria pathogenesis and biofilm assembly. Int J Mycobacteriol 2015;4:36-43. doi: 10.1016/j. ijmyco.2014.11.065

3. Halstrom S, Price P, Thomson R. Review: Environmental mycobacteria as a cause of human infection. Int $\mathrm{J}$ Mycobacteriol 2015;4:81-91. doi: 10.1016/j. ijmyco.2015.03.002

4. De Groote MA, Huitt G. Infections due to rapidly growing mycobacteria. Clin Infect Dis 2006;42:1756-63. doi: $10.1086 / 504381$

5. Falkinham JO III, Norton CD, LeChevallier MW. Factors influencing numbers of Mycobacterium avium, Mycobacterium intracellulare, and other mycobacteria in drinking water distribution systems. Appl Environ Microbiol 2001;67:1225-31. doi: 10.1128/AEM.67.3.1225-1231.2001

6. Taylor RH, Falkinham JO III, Norton CD, LeChevallier MW. Chlorine, chloramine, chlorine dioxide, and ozone susceptibility of Mycobacterium avium. Appl Environ Microbiol 2000;66:1702-5. PMCID: PMC92045

7. Le Dantec C, Duguet JP, Montiel A, Dumoutier N, Dubrou $\mathrm{S}$, Vincent V. Chlorine disinfection of atypical mycobacteria isolated from a water distribution system. Appl Environ Microbiol. 2002;68:1025-32. PMCID: PMC123737

8. Cowan MM. Plant products as antimicrobial agents. Clin Microbiol Rev 1999;12:564-82. PMCID: PMC88925

9. Bakkali F, Averbeck S, Averbeck D, Idaomar M. Biological effects of essential oils: a review. Food Chem Toxicol 2008;46:446-75. doi: 10.1016/j.fct.2007.09.106

10. Bassole IH, Juliani HR. Essential oils in combination and their antimicrobial properties. Molecules 2012;17:39894006. doi: 10.3390/molecules 17043989

11. Pichersky E, Noel JP, Dudareva N. Biosynthesis of plant volatiles: nature's diversity and ingenuity. Science 2006;311:808-11. doi: 10.1126/science. 1118510

12. Dorman HJ, Deans SG. Antimicrobial agents from plants: antibacterial activity of plant volatile oils. J Appl Microbiol 2000;88:308-16. doi: 10.1046/j.1365-2672.2000.00969.x 
13. Arjomandzadegan M, Emami N, Habibi G, et al. Antimycobacterial activity assessment of three ethnobotanical plants against Mycobacterium Tuberculosis: An In Vitro study. Int J Mycobacteriol 2016;5(Suppl 1):S108-9.

14. Jerković I, Marijanović Z. Volatile composition screening of Salix spp. nectar honey: benzenecarboxylic acids, norisoprenoids, terpenes, and others. Chem Biodivers 2010;7:2309-25. doi: 10.1002/cbdv.201000021

15. Jerković I, Kranjac M, Marijanović Z, Zekić M, Radonić A, Tuberoso CI. Screening of Satureja subspicata Vis. honey by HPLC-DAD, GC-FID/MS and UV/VIS: prephenate derivatives as biomarkers. Molecules 2016;21:377. doi: 10.3390/molecules 21030377

16. The Pherobase: Database of Insect Pheromones and Semiochemicals [displayed 19 Feb 2018]. Available at http:// www.pherobase.com

17. Andrejak C, Almeida DV, Tyagi S, Converse PJ, Ammerman $\mathrm{NC}$, Grosset JH. Characterization of mouse models of Mycobacterium avium complex infection and evaluation of drug combinations. Antimicrob Agents Chemother 2015;59:2129-35. doi: 10.1128/AAC.04841-14

18. Sarker SD, Nahar L, Kumarasamy Y. Microtitre plate-based antibacterial assay incorporating resazurin as an indicator of cell growth, and its application in the in vitro antibacterial screening of phytochemicals. Methods 2007;42:321-4. doi: 10.1016/j.ymeth.2007.01.006

19. Carson CF, Mee BJ, Riley TV. Mechanism of action of Melaleuca alternifolia (tea tree) oil on Staphylococcus aureus determined by time-kill, lysis, leakage, and salt tolerance assays and electron microscopy. Antimicrob Agents Chemother 2002;46:1914-20. doi: 10.1128/AAC.46.6.19141920.2002

20. El Kolli M, Laouer H, El Kolli H, Akkal S, Sahli F. Chemical analysis, antimicrobial and anti-oxidative properties of Daucus gracilis essential oil and its mechanism of action. Asian Pac J Trop Biomed 2016;6:8-15. doi: 10.1016/j. apjtb.2015.08.004

21. Miksusanti, Jenie BSL, Priosoeryanto BP, Syarief R, Rekso GT. Mode of action Temu Kunci (Kaempferia pandurata) essential oil on E. coli K1. 1 cell determined by leakage of material cell and salt tolerance assays. HAYATI J Biosci 2008;15:56-60. doi: 10.4308/hjb.15.2.56

22. Bajpai VK, Sharma A, Baek KH. Antibacterial mode of action of the essential oil obtained from Chamaecyparis obtusa sawdust on the membrane integrity of selected foodborne pathogens. Food Technol Biotechnol 2014;52:109-18.

23. Kalantzakis G, Blekas G, Pegklidou K, Boskou D. Stability and radical-scavenging activity of heated olive oil and other vegetable oils. Eur J Lipid Sci Tech 2006;108:329-35. doi: 10.1002/ejlt.200500314

24. Sela F, Karapandzova M, Stefkov G, Kulevanova S. Chemical composition of berry essential oils from Juniperus communis L. (Cupressaceae) growing wild in Republic of Macedonia and assessment of the chemical composition in accordance to European Pharmacopoeia. Maced Pharm Bull 2011;57:4351.

25. Hajdari A, Mustafa B, Nebija D, Miftari E, Quave CL, Novak J. Chemical Composition of Juniperus communis L. cone essential oil and its variability among wild populations in
Kosovo. Chem Biodivers 2015;12:1706-17. doi: 10.1002/ cbdv.201400439

26. Pepeljnjak S, Kosalec I, Kalođera Z, Blažević N. Antimicrobial activity of juniper berry essential oil (Juniperus communis L., Cupressaceae). Acta Pharm 2005;55:417-22. PMID: 16375831

27. Mastelić J, Miloš M, Kuštrak D, Radonić A. Essential oil and glycosidically bound volatile compounds from the needles of common juniper (Juniperus communis L.). Croat Chem Acta 2000;73:585-93.

28. Angioni A, Barra A, Russo MT, Coroneo V, Dessiä S, Cabras P. Chemical Composition of the essential oils of Juniperus from ripe and unripe berries and leaves and their antimicrobial activity. J Agric Food Chem 2003;51:3073-8. doi: 10.1021/ jf026203j

29. Chatzopoulou PS, Katsiotis ST. Study of the essential oil from Juniperus communis "Berries" (Cones) growing wild in Greece. Planta Med 1993;59:554-6. doi: 10.1055/s-2006-959760

30. Höferl M, Stoilova I, Schmidt E, Wanner J, Jirovetz L, Trifonova D, Krastev L, Krastanov A. Chemical composition and antioxidant properties of Juniper Berry (Juniperus communis L.) essential oil. Action of the essential oil on the antioxidant protection of Saccharomyces cerevisiae model organism. Antioxidants (Basel) 2014;3:81-98. doi: 10.3390/ antiox3010081

31. Haziri A, Faiku F, Mehmeti A, Govori S, Abazi S, Daci M, Haziri I, Bytyqi-Damoni A, Mele A. Antimicrobial properties of the essential oil of Juniperus communis (L.) growing wild in east part of Kosovo. Am J Pharmacol Toxicol 2013;8:12833. doi: 10.3844/ajptsp.2013.128.133

32. Glišić SB, Milivojević SŽ, Dimitrijević SI, Orlović AM, Skala DU. Antimicrobial activity of the essential oil and different fractions of Juniperus communis L. and a comparison with some commercial antibiotics. J Serb Chem Soc 2007;72:311-20. doi: 10.2298/JSC0704311G

33. Orav A, Kailas T, Muurisepp M. Chemical investigation of the essential oil from berries and needles of common juniper (Juniperus communis L.) growing wild in Estonia. Nat Prod Res 2010;24:1789-99. doi: 10.1080/14786411003752037

34. Sikkema J, de Bont JA, Poolman B. Mechanisms of membrane toxicity of hydrocarbons. Microbiol Rev 1995;59:201-22. PMCID: PMC239360

35. Sikkema J, de Bont JA, Poolman B. Interactions of cyclic hydrocarbons with biological membranes. J Biol Chem 1994;269:8022-8. PMID: 8132524

36. Trombetta D, Castelli F, Sarpietro MG, Venuti V, Cristani M, Daniele C, Saija A, Mazzanti G, Bisignano G. Mechanisms of antibacterial action of three monoterpenes. Antimicrob Agents Chemother 2005;49:2474-8. doi: 10.1128/ AAC.49.6.2474-2478.2005

37. Kovač J, Šimunović K, Wu Z, Klančnik A, Bucar F, Zhang Q, Smole Možina S. Antibiotic resistance modulation and modes of action of (-)-alpha-pinene in Campylobacter jejuni. PLoS One 2015;10 (4):e0122871. doi: 10.1371/journal. pone. 0122871

38. Hammer KA, Carson CF, Riley TV. Antifungal activity of the components of Melaleuca alternifolia (tea tree) oil. J Appl Microbiol. 2003;95:853-60. doi: 10.1046/j.1365-2672. 2003.02059.x 


\section{Antimikobakterijski potencijal eteričnog ulja plodova borovice (Juniperus communis) u pitkoj vodi}

Ispitali smo aktivnost eteričnih ulja borovice [Juniperus communis (J. communis)], smilja (Helichrysum italicum), kadulje (Salvia officinalis), lavandina (Lavandula hybrida), lovora (Laurus nobilis) i tuje (Thuja occidentalis) prema sojevima Mycobacterium avium ssp. avium (M. avium), Mycobacterium intracellulare (M. intracellulare) i Mycobacterium gordonae (M. gordonae). Za određivanje minimalnih inhibicijskih koncentracija (MIK) i minimalnih baktericidnih koncentracija (MBK) testiranih eteričnih ulja koristili smo se metodom mikrodiluacije u tekućem bujonu (Middlebrook 7H9), a za određivanje minimalne efektivne koncentracije (MEK) umjesto bujona korištena je sterilna voda iz slavine kojoj je dodano $0,05 \%$ Tweena 80 . Dvostruka serijska razrjeđenja eteričnih ulja, počevši od 0,1 do $51,2 \mathrm{mg} \mathrm{mL}^{-1}$, u tekućem bujonu ili u sterilnoj vodi iz slavine inokulirana su s mikobakterijskom suspenzijom uz dodatak resazurina. Najučinkovitije eterično ulje prema svim ispitivanim sojevima mikobakterija bilo je eterično ulje $J$. communis s MBK / MIK / MEK vrijednošću od 1,6 mg mL $\mathrm{mL}^{-1}$. Metodom plinske kromatografije i masene spektrometrije analizirano je eterično ulje J. communis. Udio monoterpena iznosio je 70,54 \%, a seskviterpena 25,9\%. Glavni monoterpenski ugljikovodici bili su $\alpha$-pinen, sabinen i $\beta$-pinen. Eterično ulje $J$. communis pokazalo je značajan inhibicijski učinak na $M$. intracellulare i M. gordonae pri MEK i na $M$. avium pri dvostrukim MEK. Elektronskom mikroskopijom kod svih triju sojeva mikobakterija nakon izlaganja djelovanju eteričnog ulja $J$. communis otkrivene su značajne morfološke promjene stanične membrane i citoplazme. Učinak eteričnog ulja $J$. communis na destrukciju stanične membrane mikobakterija potvrđen je značajnim otpuštanjem unutarstaničnog materijala mjerenjem apsorbancije supernatanta pri $260 \mathrm{~nm}$ i $280 \mathrm{~nm}$. Zaključno, u našem smo radu razvili novu metodu za ispitivanje antimikrobnog učinka eteričnih ulja ili drugih prirodnih tvari na netuberkulozne mikobakterije koja oponaša uvjete kao u vodenim sustavima. Prirodni proizvodi, osobito eterična ulja, imaju ne samo velik potencijal kao antimikrobni agensi nego i moguću praktičnu primjenu kao alternativni dezinficijensi.

KLJUČNE RIJEČI: dezinfekcija vode; Juniperus communis (J. communis); Helichrysum italicum; Lavandula hybrida; Laurus nobilis; mikrodilucija u vodi; minimalna efektivna koncentracija; Mycobacterium avium; Mycobacterium gordonae; Mycobacterium intracellulare; netuberkulozne mikobakterije; pitka voda; Salvia officinalis; Thuja occidentalis 